\title{
DEEP MICRO-HOLE DRILLING FOR HADFIELD STEEL BY ELECTRO-DISCHARGE MACHINING (EDM)
}

\author{
VRTANJE GLOBOKIH MIKROLUKENJ V JEKLA HADFIELD \\ Z METODO ELEKTRORAZREZA (EDM)
}

\author{
Volkan Yilmaz $^{1}$, Murat Sarıkaya ${ }^{2}$, Hakan Dilipak ${ }^{1}$ \\ ${ }^{1}$ Manufacturing Department, Technology Faculty, Gazi University, 06500 Ankara, Turkey \\ ${ }^{2}$ Department of Mechanical Engineering, Sinop University, 57030 Sinop, Turkey \\ msarikaya@sinop.edu.tr \\ Prejem rokopisa - received: 2014-06-23; sprejem za objavo - accepted for publication: 2014-09-05
}

doi:10.17222/mit.2014.091

\begin{abstract}
In this study, a new system for drilling deep micro-holes was designed for Hadfield steel (which is difficult to process with classical methods) with the electro-discharge-machining method (EDM) and the system was experimentally examined. The tests were carried out at three different discharge currents $(6,12$ and 24) A, three different electrode-tool rotational speeds $(200,400$ and 600) r/min, three different dielectric spray pressures $(40,80$ and 120) bar, a constant pulse duration (12 $\mu \mathrm{s})$ and a constant pulse interval $(3 \mu \mathrm{s})$. After the tests the effects of the processing parameters on the basic performance outputs (the material removal rate $-M R R)$, the electrode wear rate $(E W R)$ and the relative wear $(R W))$ were investigated. Additionally, an analysis of variance (ANOVA) was also applied to identify the most significant factor. Optimum operating parameters were determined using the desirability-function analysis through the response surface methodology (RSM). It was found that the most effective variable affecting the $M R R, E W R$ and $R W$ was the discharge current. The discharge current was found to be the most significant control factor influencing the performance of the machining process.
\end{abstract}

Keywords: deep micro-EDM, hole drilling, Hadfield steel, multi-response optimization, ANOVA

V tej študiji je bil postavljen nov sistem za vrtanje globokih mikrolukenj v jeklo Hadfield (ki se težko obdeluje z navadnimi metodami) z metodo elektroerozije (EDM) in bil tudi eksperimentalno preizkušen. Poskusi so bili izvedeni s tremi različnimi tokovi $(6,12$ in 24$) \mathrm{A}$, pri treh različnih hitrostih vrtenja orodja $(200,400$ in 600$) \mathrm{r} / \mathrm{min}$, pri treh različnih dielektričnih tlakih razprševanja $(40,80$ in 120) bar, pri konstantnem trajanju impulza $(12 \mu \mathrm{s})$ in konstantnem intervalu impulza (3 $\mu s)$. Preiskovani so bili učinki procesnih parametrov na zmogljivost (hitrost odvzema materiala $(M R R)$, stopnja obrabe elektrode $(E W R)$ in relativna obraba $(R W)$ ). Dodatno je bila uporabljena analiza variance (ANOVA) za ugotovitev najpomembnejšega faktorja. Optimalni obratovalni parametri so bili določeni z analizo funkcije odziva na metodologijo odziva površine (RSM). Ugotovljeno je bilo, da je razelektritveni tok najpomembnejši kontrolni faktor, ki vpliva na zmogljivost procesa obdelave.

Ključne besede: globoka mikro-EDM, vrtanje luknje, jeklo Hadfield, optimiranje multiodziva, ANOVA

\section{INTRODUCTION}

The diameters of the holes are becoming smaller with the developing micro-mechanical systems and the classical chip-removal methods are insufficient for obtaining micro-holes, so the researchers are focusing on new manufacturing methods. Among these methods, the most applicable and commercially used one is the processing using EDM. Easy processing of hard materials and complex geometries made this method one of the most preferred uncommon manufacturing methods. ${ }^{1}$ The most important characteristic that must be exhibited by the workpieces to be processed by EDM is electrical conductivity. The characteristics such as the workpiece hardness and toughness that are effective in the processing with conventional manufacturing methods are not important with respect to EDM. On the other hand, a good processing performance depends on the thermal and electrical conductivities of a material..$^{2-4}$ Studies of EDM are generally concentrated on the performance outputs. In the studies based on the lower-duration, low-cost and high-quality expectations of the manufacturing industry, the improvement of $M R R, E W R, R W$ and surface-roughness outputs is emphasized. ${ }^{5-8}$ Besides these studies on the EDM system, rapid hole-drilling electro-dischargemachining machines were also developed to meet the new development expectations. This new EDM technique became a production technique that is often preferred in the aviation (cooling holes in plane turbine blades), automotive (fuel injection) and medical (dental and surgical implants) areas, used for medical materials, cutting-tool cooling channels and micro-hole drilling of hard, brittle and difficult-to-process materials. ${ }^{9-12}$ In this method, small-sized processing residuals are removed from the processing area by means of a dielectric liquid sprayed at a desired pressure through a tube-type electrode of a small diameter, rotating at a specified speed. Holes with larger diameters than the one of the used electrode tool are easily produced. The most important advantage of the method is that holes can be drilled into any electrically conductive metal. Micro-EDM is an important method, especially for small pieces, micro-constituents and the production of micro-tools providing a good surface quality and high integrity. Besides, it is 
Table 1: Chemical composition of the workpiece material in mass fractions, $w / \%$

Tabela1: Kemijska sestava materiala obdelovanca v masnih deležih, w/\%

\begin{tabular}{|c|c|c|c|c|c|c|c|c|c|c|c|c|}
\hline $\mathrm{C}$ & $\mathrm{Si}$ & $\mathrm{Mn}$ & $\mathrm{P}$ & $\mathrm{S}$ & $\mathrm{Cr}$ & $\mathrm{Mo}$ & $\mathrm{Ni}$ & $\mathrm{Al}$ & $\mathrm{Co}$ & $\mathrm{Cu}$ & $\mathrm{V}$ & $\mathrm{Fe}$ \\
\hline 1.08 & 0.621 & 13.6 & 0.0152 & 0.0004 & 0.721 & 0.263 & 0.286 & 0.004 & 0.023 & 0.183 & 0.0003 & Balance \\
\hline
\end{tabular}

maintained that micro-production technology can be developed with the micro-EDM. ${ }^{13}$ In addition to the tube-like tools, the use of the tools that are not tube-like is also increasing and it is maintained that the holes obtained with the cylindrical tool with an orbital motion are more uniform than the ones made with the tool not having a rotational motion. ${ }^{14}$ It was observed that $M R R$ increased with the inverse polarity (tool '+',workpiece '-') causing the electrode wear as well. ${ }^{15}$ It is known that vibration applications give favorable results with respect to the increased $M R R$ and $M R R$ increases during vibrational processes with the shortening of the process duration. ${ }^{16,17}$

When the studies in the literature are evaluated, it is seen that hole-drilling applications using the developing EDM method are used for the micro-hole drilling processes as an alternative method. The current studies relating to all the metals are developing in the direction of drilling deep holes with desired sizes and geometries using the above types of drilling units. In deep microhole drilling applications, the main expectations are to obtain a higher MRR and lower $E W R$ and $R W$ for a small diameter and a higher hole length. The aim of this study is to meet these expectations during the drilling of micro-holes into Hadfield steel, which is hard to process

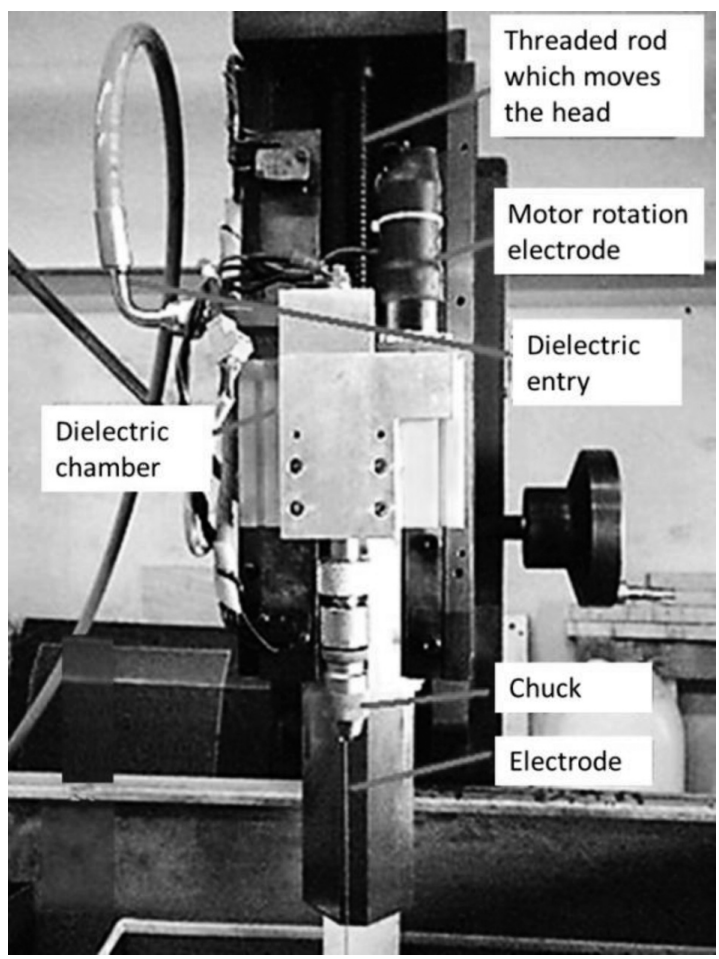

Figure 1: Pressure head

Slika 1: Tlačna glava with the classical chip-removal methods due to deformation hardening; the effects of the discharge current, the electrode-tool rotational speed and the dielectric spray pressure on the basic performance outputs were investigated. Besides, in the literature, no study on deep microhole drilling of Hadfield steel with EDM was encountered.

\section{MATERIAL AND METHOD}

\subsection{Experimental material and equipment}

As the test sample, Hadfield steel, which is hard to process with the classical chip-removal methods (because of deformation hardening) was used. Because of its unique properties such as hardness, wear resistance, strength and low thermal conductivity, this material has recently been commonly utilized in many engineering operations involving mining equipment, excavators, railways, pumping equipment, rolling-mill parts for steel factories and wear-resistant components of machining elements ${ }^{18,19}$. Test samples in the size of $10 \mathrm{~mm} \times 20 \mathrm{~mm}$ $\times 200 \mathrm{~mm}$ were prepared. The chemical composition of Hadfield material is given in Table 1. In the tests, the FURKAN brand, "EEI M50A" type EDM machine was used. A head was fixed to the moving head of the electro-erosion machine to rotate the electrode tool at different rotations and spray the process liquid (dielectric liquid) to the processing area at the desired pressure. The fixed head is seen in Figure 1. In the tests, brass electrodes with a length $400 \mathrm{~mm}$, inside diameter $0.18 \mathrm{~mm}$ and outside diameter $0.8 \mathrm{~mm}$ were used as the electrode tool. A fixed electrode and the test samples are presented in Figure 2.

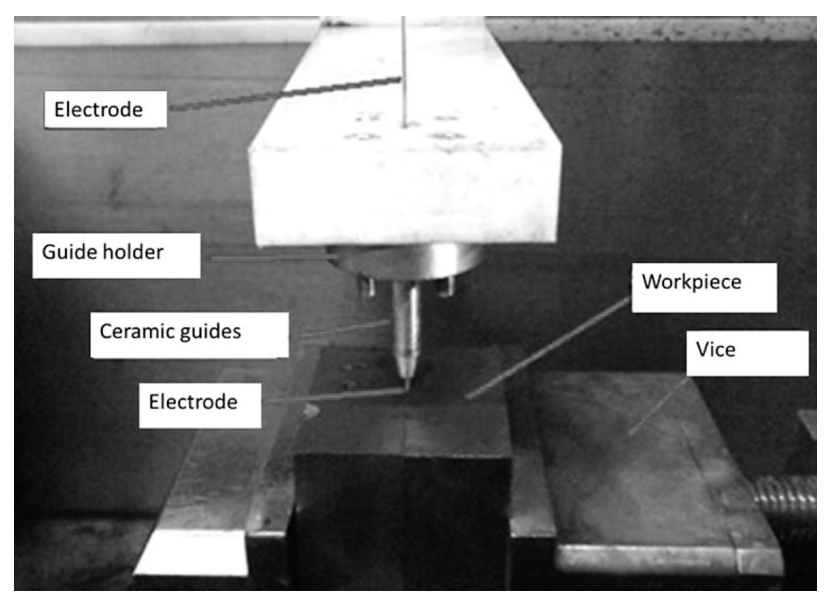

Figure 2: Fixing the electrode

Slika 2: Pritrditev elektrode 


\subsection{Experiments}

In this study, tests were made using the EDM method at three different discharge currents $(6,12$ and 24) A, three different electrode rotational speeds $(200,400$ and $600) \mathrm{r} / \mathrm{min}$, three different dielectric spray pressures $(40$, 80 and 120) bar, a constant pulse duration (12 $\mu \mathrm{s})$ and a constant pulse interval $(3 \mu \mathrm{s})$. A schematic view of the EEP unit designed for the tests is given in Figure 3. As seen in this figure, the pressure head is mounted on the moving part of the EDM machine at the $Z$-axis. Owing to the pressure head, the electrode had a rotational motion and the pressurized dielectric liquid had access to the processing area through the electrode. The rotational motion was given to the electrode by a D. A motor on the pressure head. Due to the power source added to the system, the rotational speed of the electrode was controlled and it reached the desired $\mathrm{r} / \mathrm{min}$ values. In this system, the motion of the electrode at the vertical axis was provided by another D. A motor included in the EDM machine. Dielectric liquid reached the pressure head by means of a pressure pump. The dielectric liquid pressure was continuously controlled by a manometer mounted on the by-pass mechanism. The desired dielectric liquid pressure was achieved with a set screw. With a high-pressure resistant hose, dielectric liquid was pumped to the pressure head at the pressure of up to 200 bar. Dielectric liquid was pumped to the processing area, passing through the interior part $(0.18 \mathrm{~mm})$ of the electrode fixed to the pressure head by means of a mandrel. The processes were carried out in a separate tank mounted in the process chamber. The workpieces in the process tank were fixed with a clamp. The parallelism of the clamp and the process tank was controlled with an assay balance and it was verified that they were also parallel to the EDM machine base and perpendicular to the pressure head.

\subsection{Determination of the EDM basic performance outputs (MRR, EWR and $R W$ )}

At the end of the tests, the $M R R, E W R$ and $R W$ values were calculated with the following formulas:
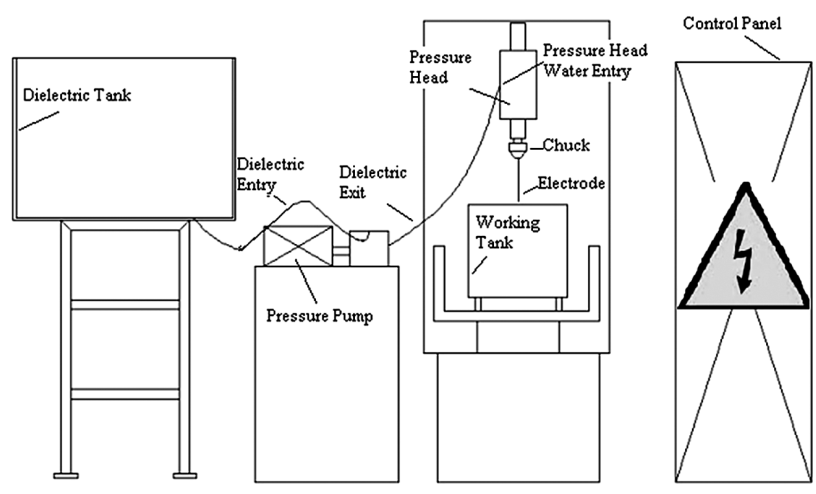

Figure 3: Schematic view of designed EEP test set-up

Slika 3: Shematski prikaz zasnovanega EEP-preizkuševališča

$$
\begin{gathered}
M R R=\frac{\text { Total workpiece wear volume }\left(\mathrm{mm}^{3}\right)}{\text { Total working time }(\mathrm{min})} \\
E W R=\frac{\text { Total electrode wear volume }\left(\mathrm{mm}^{3}\right)}{\text { Total working time }(\mathrm{min})} \\
R W=\frac{E W R}{M R R} \cdot 100
\end{gathered}
$$

$M R R$ is material removal rate $\left(\mathrm{mm}^{3} / \mathrm{min}\right), E W R$ is electrode wear rate $\left(\mathrm{mm}^{3} / \mathrm{min}\right), R W$ is relative wear $(\%)$.

\section{RESULTS AND DISCUSSION}

The hole pictures obtained after the tests are given in Figure 4 and the test results are in Table 2. The performance characteristics were specified as $M R R /\left(\mathrm{mm}^{3} / \mathrm{min}\right)$, $E W R /\left(\mathrm{mm}^{3} / \mathrm{min}\right)$ and $R W / \%$. The results were expressed graphically in order to be easily discussed and compared.

\begin{tabular}{|c|c|c|c|c|c|c|}
\hline $\begin{array}{l}\bar{\Xi} \\
\bar{\Xi} \\
\Xi \\
\Xi \\
\tilde{\Xi} \\
\tilde{U}\end{array}$ & 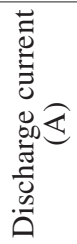 & 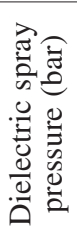 & 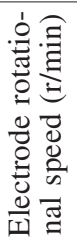 & 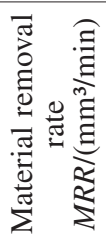 & 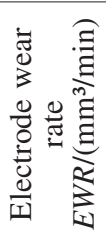 & 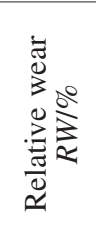 \\
\hline 1 & \multirow{9}{*}{6} & \multirow{3}{*}{40} & 200 & 1.452 & 0.473 & 32.595 \\
\hline 2 & & & 400 & 1.654 & 0.457 & 27.622 \\
\hline 3 & & & 600 & 1.801 & 0.419 & 23.282 \\
\hline 4 & & \multirow{3}{*}{80} & 200 & 1.433 & 0.519 & 36.217 \\
\hline 5 & & & 400 & 1.707 & 0.540 & 31.664 \\
\hline 6 & & & 600 & 1.808 & 0.561 & 31.043 \\
\hline 7 & & \multirow{3}{*}{120} & 200 & 2.017 & 0.613 & 30.41 \\
\hline 8 & & & 400 & 2.291 & 0.622 & 27.163 \\
\hline 9 & & & 600 & 2.173 & 0.616 & 28.344 \\
\hline 10 & \multirow{9}{*}{12} & \multirow{3}{*}{40} & 200 & 5.228 & 2.678 & 51.221 \\
\hline 11 & & & 400 & 4.932 & 2.417 & 49.015 \\
\hline 12 & & & 600 & 5.301 & 2.715 & 51.221 \\
\hline 13 & & \multirow{3}{*}{80} & 200 & 5.614 & 2.875 & 51.221 \\
\hline 14 & & & 400 & 6.524 & 3.182 & 48.782 \\
\hline 15 & & & 600 & 6.769 & 4.098 & 60.534 \\
\hline 16 & & \multirow{3}{*}{120} & 200 & 5.875 & 3.283 & 55.878 \\
\hline 17 & & & 400 & 7.218 & 3.309 & 45.845 \\
\hline 18 & & & 600 & 7.126 & 3.921 & 55.031 \\
\hline 19 & \multirow{9}{*}{24} & \multirow{3}{*}{40} & 200 & 8.815 & 10.567 & 119.88 \\
\hline 20 & & & 400 & 9.950 & 11.501 & 115.59 \\
\hline 21 & & & 600 & 9.474 & 9.722 & 102.62 \\
\hline 22 & & \multirow{3}{*}{80} & 200 & 10.527 & 10 & 94.989 \\
\hline 23 & & & 400 & 14.385 & 10.960 & 76.197 \\
\hline 24 & & & 600 & 12.632 & 9.625 & 76.197 \\
\hline 25 & & \multirow{3}{*}{120} & 200 & 11.475 & 7.898 & 68.835 \\
\hline 26 & & & 400 & 14.982 & 9.842 & 65.694 \\
\hline 27 & & & 600 & 16.452 & 8.325 & 50.6 \\
\hline
\end{tabular}

Table 2: Experimental results

Tabela 2: Eksperimentalni rezultati 


\subsection{Variation of the metal removal rate (MRR) with the processing parameters}

$M R R$ is expressed as the amount of the removed material (chip) per unit time $\left(\mathrm{mm}^{3} / \mathrm{min}\right)$ and it is one of the most important output parameters in the EDM operations. In the EDM operations, obtaining high $M R R$-values is the main requirement and the studies are focusing on this issue. The variations in the $M R R$-values obtained in the tests with the processing parameters are graphically expressed in Figures 5 and $\mathbf{6}$.

When the variation of $M R R$ with the discharge current $(I)$ is examined in Figure 5, it is seen that the $M R R$ values increase with an increase in the $I$-values. Increasing the crater dimensions (occurring on the surface of the workpiece due to electrical discharges) with the direct proportional increase in the discharge energy is the general principle of the electro-erosion processing method. The reason for this is the evaporation of a large amount of the material (through fusion) per unit time from the workpiece surface due to the increasing discharge energy with the increase in the discharge current. Namely, with the increase in the discharge current each spark becomes more severe and each time these sparks pull off a greater area from the workpiece material. So, with the increasing discharge current (I) more material is fused and evaporated in a shorter time,

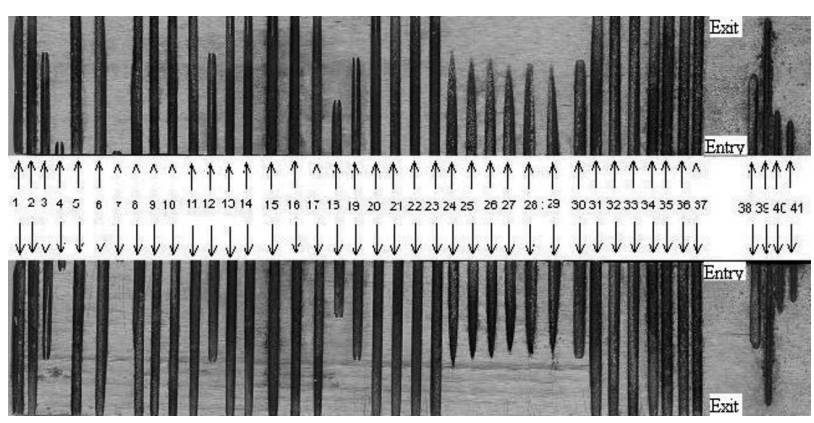

Figure 4: Hole pictures after the tests Slika 4: Videz lukenj po preizkusih

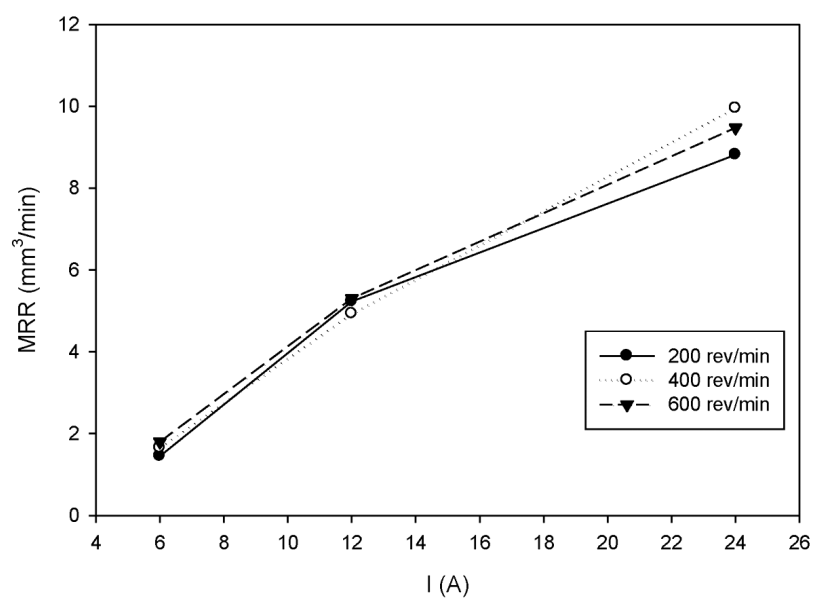

Figure 5: $M R R-I$ variation

Slika 5: Diagram $M R R-I$

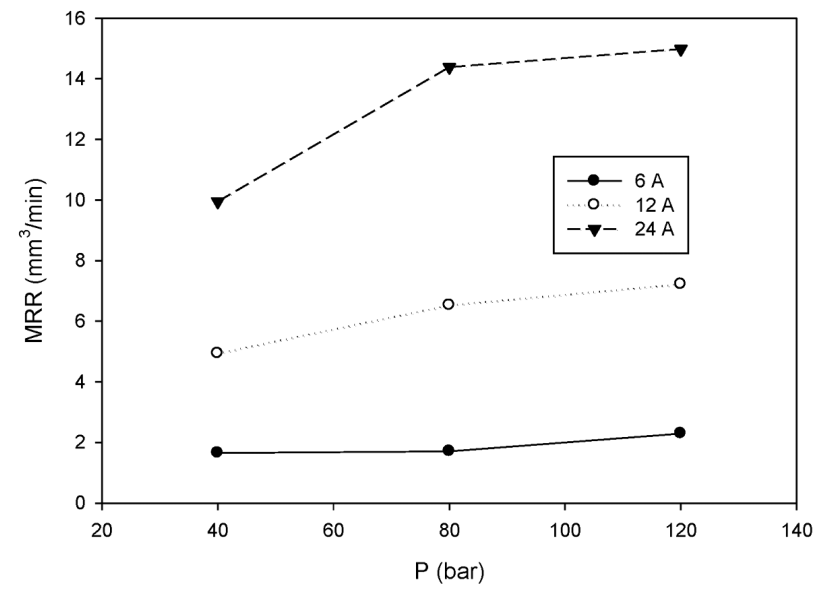

Figure 6: $M R R-P$ variation

Slika 6: Diagram $M R R-P$

causing an increase in the $M R R$-values. In the tests, the $M R R$-values obtained in the interval of $1.4-2.3 \mathrm{~mm}^{3} / \mathrm{min}$ with the $6 \mathrm{~A}$ discharge current, increased by approximately $200 \%$, to the $4.9-7.2 \mathrm{~mm}^{3} / \mathrm{min}$ interval, with the 12 A discharge current, and by approximately $90 \%$, to the $8.8-16.4 \mathrm{~mm}^{3} / \mathrm{min}$ interval, with the 24 A discharge current. When the general principle of the EDM system is taken to be the chip removing of high-energy sparks (occurring between the electrode and the workpiece) from the workpiece surface due to fusion and evaporation, the increase in the $M R R$-values with the increase in the discharge-current values is comparable with the results in $^{3-8}$. When Figures 5 and $\mathbf{6}$ are evaluated, it is seen that as the $I$-value is increased, keeping the electrode-tool rotational speed $(n)$ constant, there is a gradual increase in the $M R R$-values. This shows that in all of the tests with the increasing discharge-current values the $M R R$-values increase without an exception. With the increasing electrode-tool rotational speed, the $M R R$ performance values also increased. In the $6 \mathrm{~A}$ dischargecurrent tests at the 40 bar dielectric liquid spray pressure, with an increase in the electrode-tool rotational speed from $200 \mathrm{r} / \mathrm{min}$ to $400 \mathrm{r} / \mathrm{min}$, the $M R R$-values increased by $14 \%$, and with an increase from $400 \mathrm{r} / \mathrm{min}$ to 600 $\mathrm{r} / \mathrm{min}, M R R$ exhibited an increase of $9 \%$. This increase was $19 \%$ and $6 \%$ at the 80 bar dielectric liquid pressure. It is also valid for the other tests. The increase in the tool rotational speed provided a continuous and rapid flow of dielectric liquid to the processing area and, consequently, the formation of continuous sparks in the processing area made the processing more efficient and uninterrupted. The continuous spark discharge became the most important reason for the increase in the $M R R$ values. When the experimental values are considered the increase in the dielectric spray pressure, together with the rotational speed, makes a significant contribution to the effective washing of the processing area. In the $12 \mathrm{~A}$ discharge-current tests, at the $200 \mathrm{r} / \mathrm{min}$ electrode-tool rotational speed, with the increase in the dielectric liquid spray pressure from 40 bar to 80 bar, the $M R R$-values 
increased by $8 \%$, and with an increase from 80 bar to 120 bar, MRR exhibited an increase of $5 \%$. The main reason for this is a faster motion of the fluid dielectric liquid in the area of the rotation of the tool. Due to this rapid motion, the dielectric liquid moves away from the side spaces between the electrode tool and the workpiece faster and the hole-drilling operation is carried out more effectively. When an evaluation of the $M R R$-values is made it can be found that the spray-type dielectric-application method is very effective. These results show parallelism with the studies in the literature. With respect to the spray-type dielectric-liquid applications, the reports in the literature state that higher $M R R$-values are obtained with the lateral-spray type, the reasons being a low temperature, a smaller amount of the processingarea contamination and a lower volume of gas in the processing space compared to the other methods. ${ }^{15,16}$ With the spray-type washing used in the tests, an effective washing of the processed products can be carried out. This way a short-circuit formation of a continuous, clean dielectric liquid decreases and the sparks in the clean processing space affect the workpiece more effectively, increasing the $M R R$. Thus, for the higher $M R R$-values in the EDM operations, it was determined that the discharge current, the electrode-tool rotational speed and the dielectric spray pressure must be selected at high intervals.

\subsection{Variation in the electrode-wear rate $(\mathrm{EWR})$ with the processing parameters}

Another important performance characteristic in the EDM applications is the EWR-value. The sparks created between the workpiece and the electrode in the EDM operations not only fuse the area and cause evaporation of the workpiece but they also cause evaporation of a certain area on the electrode tool. This loss of the electrode tool is expressed as EWR and in this study EWR was calculated as the decrease in the electrode volume per unit time $\left(\mathrm{mm}^{3} / \mathrm{min}\right)$. EWR primarily depends on the

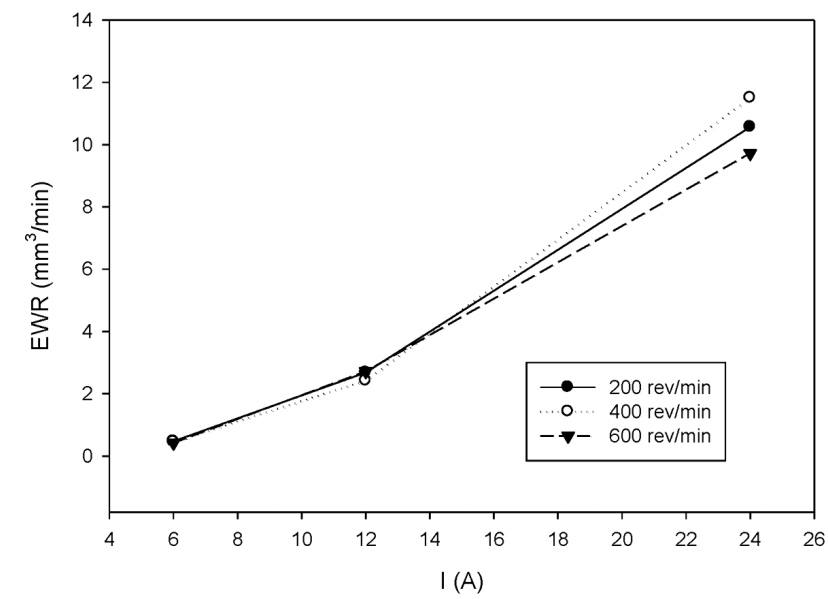

Figure 7: $E W R-I$ variation

Slika 7: Diagram $E W R-I$ thermal and electrical properties of the electrode material and then also on the processing parameters ${ }^{7}$. The relationships between the EWR-values and the dischargecurrent $(I)$, electrode-tool-rotational-speed and dielectric-spray-pressure values are graphically shown in Figures 7 and 8.

When the variation in the EWR of the electrode tool (brass) (Figure 7) with the discharge current $(I)$ is examined it is observed that the electrode-tool EWR increases with the increase in the $I$-value, keeping the tool rotational speed constant. It was also found that due to the increase in the $E W R$ of the electrode tool more material is fused and evaporated, proportionally with the applied discharge energy. As seen from Figure 4, when the discharge current is $6 \mathrm{~A}$, the $E W R$-values are in the interval of $0.4-0.6 \mathrm{~mm}^{3} / \mathrm{min}$ and in the case of the $12 \mathrm{~A}$ discharge current the $E W R$-values increase by approximately $500 \%$ and take place in the $2.4-4 \mathrm{~mm}^{3} / \mathrm{min}$ interval. With the discharge current of $24 \mathrm{~A}$, the $E W R$-values increase by approximately $300 \%$ and rise to the $9.6-11.5 \mathrm{~mm}^{3} / \mathrm{min}$ interval. According to these results, the increases in the discharge-current values caused very high increases in the brass-tool $E W R$-values. The reason for this is that the electrode has a fine structure and its inside space is empty. This fine structure heats up very rapidly by losing its electrical resistance with the increase in the tool discharge-current values. In the tests using 12 A and 24 A this was explicitly evident. During the processing these currents heated up the fine electrode material in a very short time and during the flowing of the sparks from the tool to the workpiece, big pieces were pulled off due to fusion, causing an increase in the EWR-values. From Figures $\mathbf{7}$ and $\mathbf{8}$ it is seen that in the tests with the constant dielectric spray pressure and $I$-value, with an increase in the rotational speed the $E W R$-values had a tendency to increase. Since the increasing rotational speed provided a continuous, clean processing liquid in the processing area, more sparks occurred and an increased spark discharge increased the

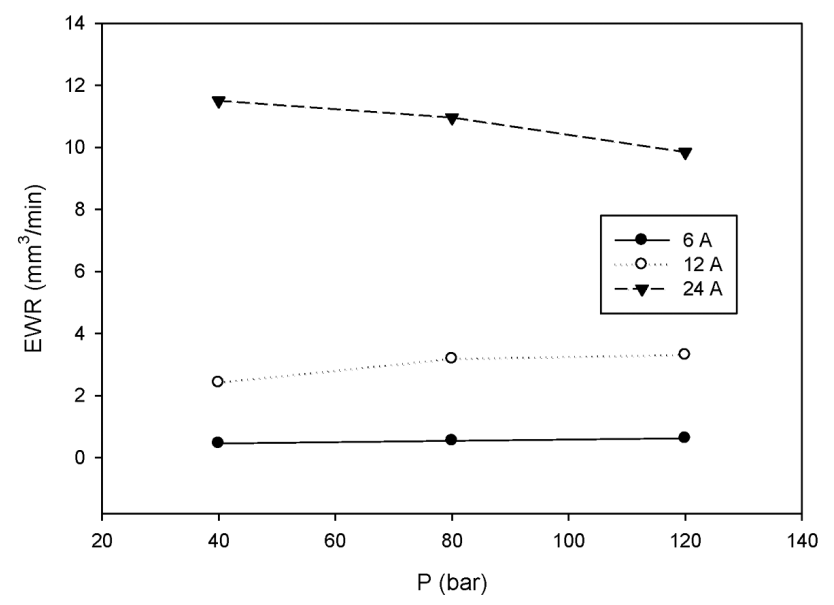

Figure 8: $E W R-P$ variation

Slika 8: Diagram $E W R-P$ 
EWR. ${ }^{3,7,10}$ Consequently, in the continuously cleaned processing area an effective and high amount of spark discharge caused more material to fuse and evaporate from the finely structured tool and, naturally, also caused the EWR to increase. This increase changes depending on the physical property of the electrode material, the discharge energy, the pulse duration, the dielectric spray characteristic and the type. When the relationship between the $E W R$ and the dielectric spray pressure is examined in Figure 8, it is seen that the EWR-values increase with the increase in the dielectric spray pressure. With the increase in the dielectric spray pressure from 40 bar to 80 bar at the $6 \mathrm{~A}$ discharge current and $200 \mathrm{r} / \mathrm{min}$ electrode-tool rotational speed, the EWR-values increased by $9 \%$, and with the increase from 80 bar to 120 bar, the $E W R$-values increased by $20 \%$. The increases were $20 \%$ and $15 \%$ at the $400 \mathrm{r} / \mathrm{min}$ electrode-tool rotational speed and $37 \%$ and $9 \%$ at the 600 $\mathrm{r} / \mathrm{min}$ electrode-tool rotational speed. The reason for the increase was found to be the rapid cleaning of the processing area with the increase in the dielectric spray pressure and the effective spark discharges. Besides, it is also known from the literature that the processed products are moved away from the processing area more effectively with the spraying of dielectric from the tool. ${ }^{20-22}$ So, the decreases in EWR depending on the dielectric spray pressure relieve the processing area of effective spraying in electro-erosion drilling, clean the processing area more rapidly and, with a higher energy spark discharge, pull off a smaller amount of electrode material from the tube-like tool (from the point of separating the sparks).

\subsection{Variation in the relative wear $(\mathrm{RW})$ with the pro- cessing parameters}

$R W$ is a significant output parameter expressing the relationship between $E W R$ and $M R R$ during each process in the EDM operations. A graphical expression of the
$R W$-values calculated with the data from the tests is given in Figures 9 and $\mathbf{1 0}$.

From Figure 9, it is seen that the increases in the $R W$-values also occurred, being parallel to the increase in the discharge current. The reason for this was a higher increase in the $E W R$-values with respect to the $M R R$-values at high discharge-current values. In the tests with the $6 \mathrm{~A}$ discharge current, the $R W$-values were in the interval of $23-33 \%$ and in the tests with the $12 \mathrm{~A}$ discharge current the interval increased to $49-52 \%$. This shows that both $E W R$ - and $M R R$-values increased by the same, small amount during the increase in the discharge-current value from $6 \mathrm{~A}$ to $12 \mathrm{~A}$. The $R W$-values exhibited a significant increase with the 24 A discharge current compared to the results obtained with the $6 \mathrm{~A}$ and $12 \mathrm{~A}$ values and the $R W$-values increased to the $102-120 \%$ interval. This was explained with the fact that the finely structured and empty electrode tool had a higher $E W R$ with respect to the $M R R$ at high discharge-current values. As an empty and finely structured electrode tool rapidly loses its electrical resistance at a high discharge current, it causes the EWR-values to increase. So, when $R W$ is calculated with the $(E W R /$ $M R R) \times 100$ formula, these increases in the $E W R$-values that are higher than the $M R R$-values also cause an increase in the $R W$-values. In Figure 9 it is seen that the $R W$-values have a tendency to increase with the rotational speed applied to the electrode tool. This was explained with the increase in the $E W R$-values caused by the increasing electrode rotational speed. In Figure 10 it is observed that the $R W$-values decrease with the increase in the dielectric spray pressure. Processing residuals can be easily removed from the processing area owing to the spray-type washing applied in the tests (in line with the studies in the literature $)^{21-24}$ and for this reason the $M R R$-values increase in the clean processing area. So, increasing the $M R R$-values more than the $E W R$-values caused a decrease in the $R W$-values.

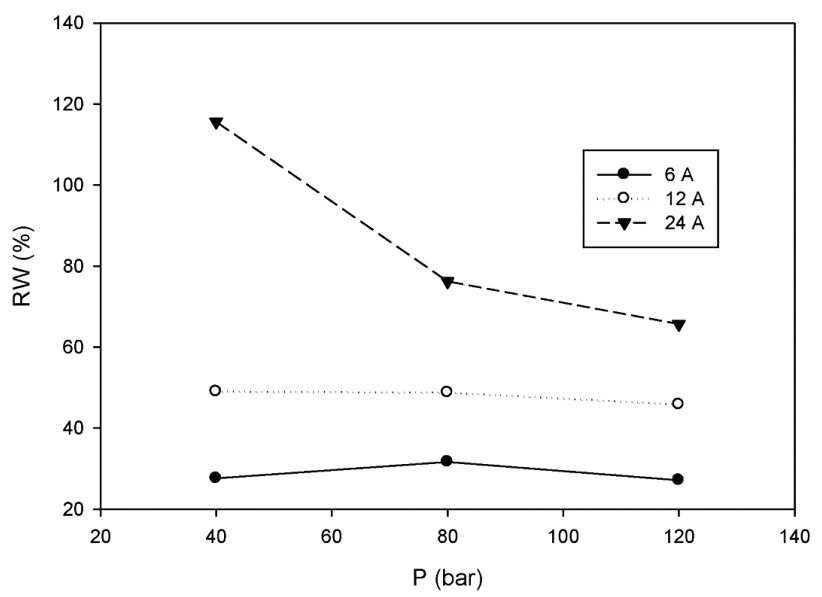

Figure 10: $R W-P$ variation

Slika 10: Diagram $R W-P$ 


\subsection{Analysis of variance (ANOVA)}

Analysis of variance (also known as ANOVA) is a statistical method used to identify individual interactions of all the control factors in the experimental results. In the present work, ANOVA was used to determine the effects of the discharge current, the dielectric spray pressure and the electrode rotational speed on $M R R$, $E W R$ and $R W$. ANOVA results for the responses are given in Table 3. The ANOVA analysis was performed at the $95 \%$ confidence level and $5 \%$ significance level. The $F$-values of the control factors indicated the significance of the control factors with the ANOVA anal ysis. ${ }^{19,25-27}$ The percentage contribution of each parameter is shown in the last column of the ANOVA table. This column shows the influence rates of the control factors for the experimental results. In addition, ANOVA results are also summarized as a column chart in Figure 11. In Table 3, the percent contributions of the factors such as discharge current, dielectric spray pressure and electrode rotational speed to the $M R R$ were determined as $88.1 \%$, $4.6 \%$ and $1.7 \%$, respectively. Therefore, the most effective variable affecting the $M R R$ was the discharge current $(88.1 \%)$. It was seen that the discharge current and dielectric spray pressure significantly affect the $M R R$ at the reliability level of $95 \%$ or the significance level of $5 \%$, because the $P$-values of these variables are lower than $0.05 .{ }^{26}$ According to Table 3, the percent contributions of the input parameters to the EWR were found to be $96.9 \%, 0.2 \%$ and $0.2 \%$, respectively, and the error was $2.7 \%$. It was determined that the most effective parameter with respect to the EWR is the discharge current. Moreover, among the input parameters, only the discharge current significantly affects the $E W R$ at the reliability level of $95 \%$ or the significance level of $5 \%$.

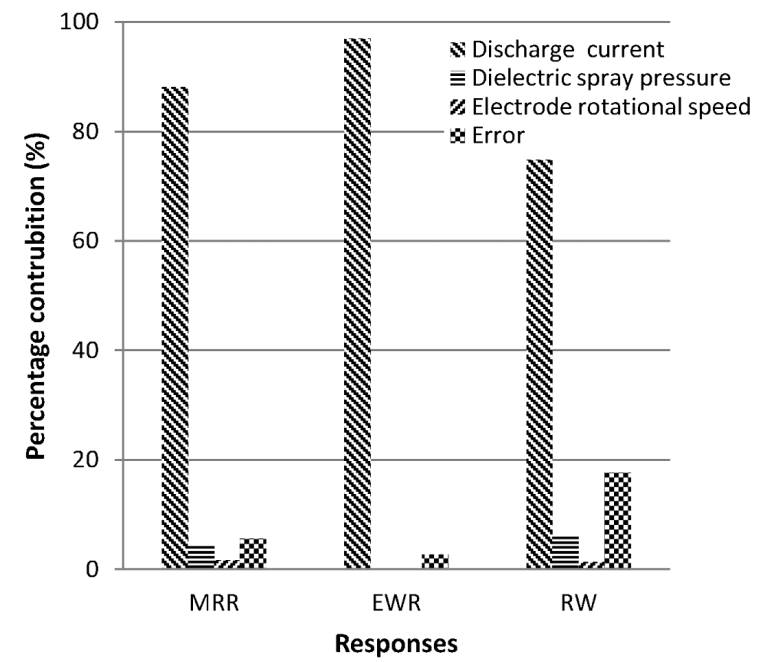

Figure 11: Histogram of the ANOVA results Slika 11: Histogram rezultatov ANOVA

From Table 3, the effects of the control factors on the $R W$ were obtained as $74.8 \%, 6.2 \%$ and $1.3 \%$, and the error amounted to $17.7 \%$ of the contribution rate. The ANOVA table indicated that with respect to the $R W$, the most effective parameter is the discharge current.

\subsection{Multi-response optimization of the EDM parame- ters based on RSM}

Mono-response optimization is a common and popular method to solve the problems of optimization approaches. But the method cannot be used to determine the optimum combination of the machining parameters that simultaneously optimize the output parameters. ${ }^{28}$ To overcome this problem in the present work, a multi-

Table 3: ANOVA results for means

Tabela 3: ANOVA povprečni rezultati

\begin{tabular}{|c|c|c|c|c|c|c|}
\hline Variation of source & $\begin{array}{l}\text { Degree of } \\
\text { freedom } \\
\text { (DF) }\end{array}$ & $\begin{array}{c}\text { Sum of squares } \\
\text { (SS) }\end{array}$ & $\begin{array}{c}\text { Mean of } \\
\text { squares } \\
(\mathrm{MS})\end{array}$ & $F$-ratio & $P$-value & $\begin{array}{c}\text { Contribution } \\
(\%)\end{array}$ \\
\hline \multicolumn{7}{|c|}{$M R R$} \\
\hline Discharge current & 2 & 478.516 & 239.258 & 156.96 & 0.000 & 88.1 \\
\hline Dielectric spray pressure & 2 & 24.893 & 12.447 & 8.17 & 0.003 & 4.6 \\
\hline Electrode rotational speed & 2 & 9.216 & 4.608 & 3.02 & 0.071 & 1.7 \\
\hline Error & 20 & 30.487 & 1.524 & & & 5.6 \\
\hline Total & 26 & 543.112 & & & & 100 \\
\hline \multicolumn{7}{|c|}{$E W R$} \\
\hline Discharge current & 2 & 412.892 & 206.446 & 358.86 & 0.000 & 96.9 \\
\hline Dielectric spray pressure & 2 & 0.882 & 0.441 & 0.77 & 0.478 & 0.2 \\
\hline Electrode rotational speed & 2 & 0.912 & 0.456 & 0.79 & 0.466 & 0.2 \\
\hline Error & 20 & 11.506 & 0.575 & & & 2.7 \\
\hline Total & 26 & 426.191 & & & & 100 \\
\hline \multicolumn{7}{|c|}{$R W$} \\
\hline Discharge current & 2 & 14205.4 & 7102.7 & 42.16 & 0.000 & 74.8 \\
\hline Dielectric spray pressure & 2 & 1175.1 & 587.5 & 3.49 & 0.050 & 6.2 \\
\hline Electrode rotational speed & 2 & 253.6 & 126.8 & 0.75 & 0.484 & 1.3 \\
\hline Error & 20 & 3369.5 & 168.5 & & & 17.7 \\
\hline Total & 26 & 19003.6 & & & & 100 \\
\hline
\end{tabular}




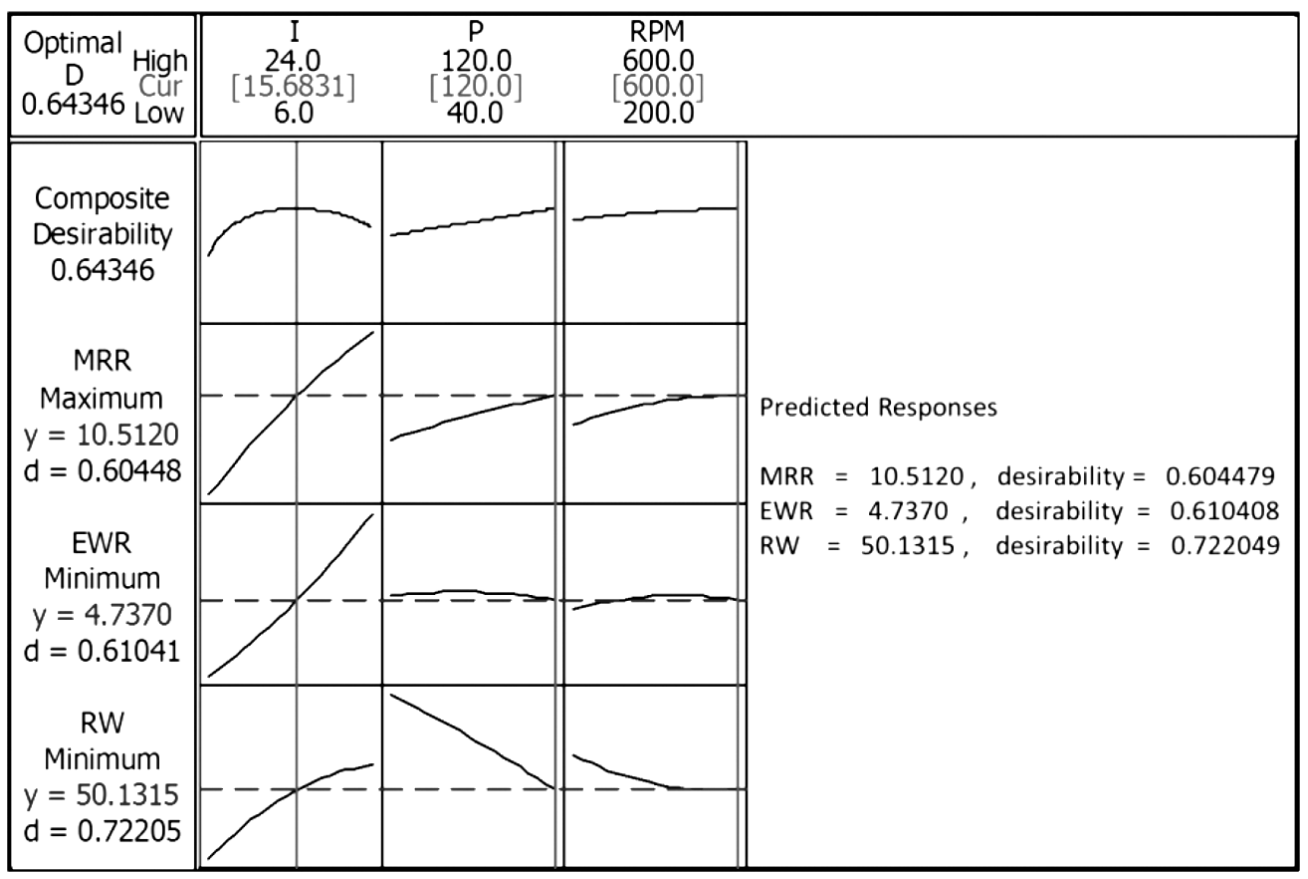

Figure 12: Plot of multi-response optimization

Slika 12: Prikaz multiodzivne optimizacije

Table 4: Best global solutions for multi-optimization Tabela 4: Najboljše celotne rešitve multioptimizacije

\begin{tabular}{|c|c|c|c|c|c|c|c|c|c|c|c|}
\hline \multirow[t]{2}{*}{ Response } & \multirow[t]{2}{*}{ Goal } & \multicolumn{3}{|c|}{$\begin{array}{c}\text { Global solution } \\
\text { (Multi-optimization) }\end{array}$} & \multirow[t]{2}{*}{ Lower } & \multirow[t]{2}{*}{ Target } & \multirow[t]{2}{*}{ Upper } & \multirow[t]{2}{*}{ Weight } & \multirow[t]{2}{*}{ Imp. } & \multirow[t]{2}{*}{ Predicted } & \multirow{2}{*}{$\begin{array}{l}\text { Desira- } \\
\text { bility }\end{array}$} \\
\hline & & I/A & $P /$ bar & $\mathrm{r} / \mathrm{min}$ & & & & & & & \\
\hline$M R R$ & Max. & 15.6831 & 120 & 600 & 1.4332 & 16.4525 & 16.453 & 1 & 1 & 10.512 & 0.604479 \\
\hline$E W R$ & Min. & 15.6831 & 120 & 600 & 0.4194 & 0.4194 & 11.502 & 1 & 1 & 4.7370 & 0.610408 \\
\hline$R W$ & Min. & 15.6831 & 120 & 600 & 23.282 & 23.282 & 119.880 & 1 & 1 & 50.1315 & 0.722049 \\
\hline
\end{tabular}

response optimization was performed to determine the objective values of three responses, i.e., $M R R, E W R$, and $R W$ in deep micro-hole drilling of Hadfield steel with EDM. The multi-response optimization was employed through the Minitab 16.0 software based on the response surface methodology (RSM). ${ }^{26}$ The graph of the multiresponse optimization plotted in Minitab is shown in Figure 12. In this figure, each column of the plots shows the machining parameters, and the responses are shown by each row of the plots

The objective value of each response, namely $y$, is displayed along with the desirability value range, namely $d$, which is between 0 and 1 as shown in the figure. If $d=$ 0 or approaches to 0 , then the output is clearly undesirable. If $d=1$ or approaches to 1 , then the output perfectly meets the target value. A higher value of desirability indicates a better optimization. ${ }^{26}$ The highest desirability value is favored for the best solution of deep micro-EDM drilling. The goal, lower value, target value, upper value, mass, the importance of the factors and the best global solution were determined for the multi-response optimization as shown in Table 4. According to Table $\mathbf{4}$ and Figure 12, the optimization values are found to be
$10.512 \mathrm{~mm}^{3} / \mathrm{min}, 4.737 \mathrm{~mm}^{3} / \mathrm{min}$ and $50.1315 \%$ for $M R R, E W R$ and $R W$, respectively. Individual desirability values are $0.60448,0.61041$ and 0.72205 . Moreover, the composite desirability value is 0.643461 for all the responses. The levels of the control parameters are found to be $15.6831 \mathrm{~A}$ for the discharge current, $120 \mathrm{bar}$ for the dielectric spray pressure and $600 \mathrm{r} / \mathrm{min}$ for the electrode rotational speed for the multi-response optimization in deep micro-hole drilling of Hadfield steel by EDM.

\section{CONCLUSION}

In this study, using the EDM method, deep microhole drilling was carried out on Hadfield steel which is hard to process with classical chip-removing methods due to deformation hardening. The effects of the processing parameters of deep micro-hole drilling applications (discharge current, electrode tool rotational speed and dielectric spray pressure) on the processing performance outputs (MRR, EWR, $R W$ ) were examined experimentally. The results are given below.

- By means of the installed system, the holes with a diameter $0.8 \mathrm{~mm}$ and length $20 \mathrm{~mm}$ were drilled into 
Hadfield steel. The most important parameter affecting the drilling durations was the discharge current. Increasing the electrode-tool rotational speed and dielectric spray pressure provided significant contributions to an easy drilling of the holes.

- When the $M R R$ results were considered, a significant increase in the $M R R$-values was observed, related to the increase in the discharge-current values. The $M R R$-values had a tendency to increase with the increase in the electrode-tool rotational speed. Owing to the increasing dielectric spray pressure, the processing area always remained clean and the $M R R$ values increased accordingly.

- According to the EWR results, the EWR-values increased with the increase in the discharge current. The increase in the EWR-values was explained with a finely structured and empty electrode tool. The $E W R$-values increased with the increasing electrodetool rotational speeds and decreased with the increasing dielectric spray pressure.

- When the $R W$-values were taken into consideration, the $R W$-values also increased depending on the increase in the discharge current. This was explained with the fact that the $E W R$-values increased more than the $M R R$-values because of the rise in the discharge current. The $R W$-values increased with the increase in the electrode-tool rotational speeds but decreased with the increasing dielectric spray pressure.

- From the results of ANOVA for all the responses, it was found that the most effective variable affecting the $M R R, E W R$ and $R W$ was the discharge current. Moreover, it was seen that the discharge current significantly affected the $M R R, E W R$ and $R W$ at the reliability level of $95 \%$ or the significance level of $5 \%$.

- From the multi-response optimization results based on RSM, the optimum values were found to be $10.512 \mathrm{~mm}^{3} / \mathrm{min}, 4.737 \mathrm{~mm}^{3} / \mathrm{min}$ and $50.1315 \%$ for $M R R, E W R$ and $R W$. The levels of the control parameters for the optimum results were found to be 15.6831 A for the discharge current, 120 bar for the dielectric spray pressure and $600 \mathrm{r} / \mathrm{min}$ for the electrode rotational speed in deep micro-hole drilling of Hadfield steel with EDM.

\section{REFERENCES}

${ }^{1}$ V. Yilmaz, Experimental investigation of drillability of micro holes using electro discharge machining, Ph. D. Thesis, Gazi University Graduate School of Natural and Applied Sciences, Ankara, 2013

${ }^{2}$ P. C. Pandey, H. S. Shan, Modern machining processes, Tata McGraw-Hill Publishing Company Limited, New Delhi 1980, 84-114

${ }^{3}$ R. K. Springborn, Non-traditional machining processes, American Society of Tool and Manufacturing Engineers, USA 1967

${ }^{4}$ H. M. Chow, B. H. Yan, F. Y. Huang, J. C. Hung, Study of added powder in kerosene for the micro-slit machining of titanium alloy using electro-discharge machining, Journal of Materials Processing Technology, 101 (2000), 95-103, doi:10.1016/S0924-0136(99) 00458-6
${ }^{5}$ Z. E. Ergün, C. Çoğun, Experimental investigation on workpiece surface characteristics in electric discharge machining (EDM), J. Fac. Eng. Arch. Gazi Univ., 21 (2006) 3, 427-441

${ }^{6}$ A. Özgedik, C. Çoğun, An Investigation on the effect of the applied machining tank vibrations on the machining performance in electrical discharge machining, Electronic Journal of Machine Technologies, 8 (2011) 3, 13-25

${ }^{7}$ A. Özgedik, C. Çoğun, Experimental investigation of the electrode front surface wear in electrical discharge machining, Engineer and Machinery, 521 (2003), 21-28

${ }^{8}$ C. Çoğun, B. Kocabaş, A. Özgedik, Experimental and theoretical investigation of workpiece surface profiles in electrical discharge machining (EDM), J. Fac. Eng. Arch. Gazi Univ., 19 (2004) 1, 97-106

${ }^{9}$ V. Yilmaz, H. Dilipak, Method of electro discharge machining (EDM) micro hole drilling system design, IV. UTIS 2013, Kuşadas1, Turkey, 2013, 151-159

${ }^{10}$ F. N. Leao, Optimisation of EDM fast holedrilling through evaluation of dielectric and electrode materials, Proceedings of COBEM 2005, 18th International Congress of Mechanical Engineering, Ouro Preto, MG, 2005

${ }^{11}$ P. Kuppan, A. Rajadurai, S. Narayanan, Influence of EDM process parameters in deep hole drilling of Inconel 718, International Journal of Advanced Manufacturing Technology, 38 (2008) 1-2, 74-84, doi:10.1007/s00170-007-1084-y

${ }^{12}$ T. Asokan, S. S. Reddy, P. D. E. Costa, Electrical discharge drilling of titanium alloys for aerospace applications, Proceedings of $19^{\text {th }}$ AIMTDR conference, IIT Madras, Chennai, 2000, 161-165

${ }^{13}$ D. T. Pham, S. S. Dimov, S. Bigot, A. Ivanov, K. Popov, MicroEDM-recent developments and research issues, Journal of Materials Processing Technology, 149 (2004), 50-57, doi:10.1016/j.jmatprotec. 2004.02.008

${ }^{14}$ E. Bamberg, S. Heamawatanachai, Orbital electrode actuation to improve efficiency of drilling micro-holes by micro-EDM, Journal of Materials Processing Technology, 209 (2009), 1826-1834, doi:10.1016/j.jmatprotec.2008.04.044

${ }^{15} \mathrm{~B}$. H. Yan, C. C. Wang, The machining characteristics of $\mathrm{Al}_{2} \mathrm{O}_{3}$ / 6061Al composite using rotary electro-discharge machining with a tube electrode, Journal of Materials Processing Technology, 95 (1999) 1-3, 222-231, doi:10.1016/S0924-0136(99)00322-2

${ }^{16}$ W. Koenig, R. Weill, R. Wertheim, W. I. Jutzler, The flow fields in the working gap with electro-discharge-machining, Annals of the CIRP, 25 (1977) 1, 71-76

${ }^{17}$ O. Yilmaz, A. T. Bozdana, M. A. Okka, İ. H. Filiz, An intelligent and automated system for EDM hole drilling of super alloys, $5^{\text {th }}$ International Conference on Responsive Manufacturing - Green Manufacturing, Ningbo, China, 2010

${ }^{18}$ D. Canadinc, H. Sehitoglu, H. J. Maier, Y. I. Chumlyakov, Strain hardening behavior of aluminum alloyed Hadfield steel single crystals, Acta Materialia, 53 (2005), 1831-1842, doi:10.1016/ j.actamat.2004.12.033

${ }^{19} \mathrm{~T}$. Kivak, Optimization of surface roughness and flank wear using the Taguchi method in milling of Hadfield steel with PVD and CVD coated inserts, Measurement, 50 (2014), 19-28, doi:10.1016/ j.measurement.2013.12.017

${ }^{20}$ K. H. Ho, S. T. Newman, State of the art electrical discharge machining (EDM), International Journal of Machine Tools \& Manufacture, 43 (2003), 1287-1300, doi:10.1016/S0890-6955(03)00162-7

${ }^{21}$ S. L. Chen, B. H. Yan, F. Y. Huang, Influence of kerosene and distilled water as dielectrics on the electric discharge machining characteristics of Ti-6Al-4V, Journal of Materials Processing Technology, 87 (1999) 1-3, 107-111, doi:10.1016/S0924-0136(98) 00340-9

${ }^{22}$ N. Mohri, M. Suzuki, M. Furuya, N. Saito, Electrode wear process in electrical discharge machining, Annals of the CIRP, 44 (1995) 1 , 165-168, doi:10.1016/S0007-8506(07)62298-7 
${ }^{23}$ M. Znidarsic, M. Junkar, Deep Small Hole Drilling with EDM, Proceedings of 4th International Conference on Advanced Manufacturing Systems and Technology, Udine, 1996, 527-533

${ }^{24}$ H. S. Liu, B. H. Yan, C. L. Chen, F. Y. Huang, Application of microEDM combined with high-frequency dither grinding to improve micro-hole machining, International Journal of Machine Tools \& Manufacture, 46 (2006), 80-87, doi:10.1016/j.ijmachtools.2005.03. 017

${ }^{25}$ A. Kadirvel, P. Hariharan, Optimization of the die-sinking microEDM process for multiple performance characteristics using the Taguchi-based grey relational analysis, Mater. Tehnol., 48 (2014) 1, $27-32$
${ }^{26}$ M. Sarikaya, A. Gullu, Taguchi design and response surface methodology based analysis of machining parameters in CNC turning under MQL, Journal of Cleaner Production, 65 (2014), 604-616, doi:10.1016/j.jclepro.2013.08.040

${ }^{27}$ M. Sarikaya, H. Dilipak, A. Gezgin, Optimization of the process parameters for surface roughness and tool life in face milling using the Taguchi analysis, Mater. Tehnol., 49 (2015) 1, 139-147

${ }^{28}$ M. Sarikaya, V. Yilmaz, H. Dilipak, Modeling and multi-response optimization of milling characteristics based on Taguchi and gray relational analysis, Proc IMechE Part B: J Engineering Manufacture, (2015), doi:10.1177/0954405414565136 